\title{
Well-differentiated (Marschalko-type) plasmacytoma resembling thyroid follicular structures
}

\author{
César O. Lara-Torres · Carlos Ortiz-Hidalgo
}

Received: 26 June 2008 / Accepted: 28 July 2008 /Published online: 22 August 2008

(C) Springer-Verlag 2008

\section{Dear Editor:}

Plasma cell neoplasms may display diverse cytoarchitectural variations, including a diffuse, nested, paragangliomatous, and angiomatoid arrangements [1]. We present herein a case of a well-differentiated (Marschalko-type) plasmacytoma in which neoplastic plasma cells arranged in a pseudofollicular configuration resemble thyroid follicles filled with 'colloid-like' material.

The patient, a 62-year-old female, presented to the ABC Medical Center in Mexico City with a month-long history of bilateral epistaxis and nasal congestion. On clinical examination, a large polypoid tumor with well-defined borders was identified within the nasal cavity. The diagnosis of a benign tumor was established by clinical criteria and the patient underwent transpalatine resection of the mass.

Histologically, the tumor was composed of thin strands of well-differentiated (Marschalko-type) neoplastic plasma cells that limited roughly rounded-to-irregular spaces with sharp scalloped borders filled with a homogeneous eosinophilic_PAS-positive - proteinaceous ('colloid-like') material, resembling thyroid follicle structures (Fig. 1a-b). Approximately $80 \%$ of the tumor was composed by this particular arrangement, whereas the remaining neoplasm exhibited solid growth pattern.

C. O. Lara-Torres $\cdot$ C. Ortiz-Hidalgo

Department of Pathology,

The American British Cowdray Medical Center,

Mexico City, Mexico

C. O. Lara-Torres $\cdot$ C. Ortiz-Hidalgo $(\square)$

Department of Tissue and Cell Biology, School of Medicine,

Universidad Panamericana,

Sur 136 \#116 Col. Las Américas,

Mexico City 01120, Mexico

e-mail: cortiz@abchospital.com
The neoplastic plasma cells were negative for CD20 (Clone L26 BioSb; 1:50) and showed strong membranal immunoreactivity for CD138 (Clone B-B4, Cell Marque; 1:50) (Fig. 1c) as well as kappa light chain restriction (Clone L1C1, Cell Marque; 1:4,000). Likewise, the 'colloid-like' material showed kappa light chain restriction, demonstrating that it was, in fact, immunoglobulin secreted by the neoplastic plasma cells (Fig. 2). Congo red staining was negative.

Kremer et al. have demonstrated that primary extramedullary plasmacytoma shows significant immunophenotypic differences with multiple myeloma with absence to low reactivity for cyclin D1, CD56, bcl-2, p21, and p53 [1]. Thus, we evaluated the expression of these markers in our case. The immunohistochemical analysis of CD56 (Clone 123C3D5, Cell Marque; 1:50), p21 (Clone SX118, Dako; 1:20), and Ki-67 (Clone K-3, Cell Marque; 1:25) revealed that only scattered neoplastic cells $(1-2 \%)$ were positive. Weak cytoplasmic positivity for bcl-2 (Clone 124, Dako; 1:50) was identified in $<15 \%$ of the neoplastic cells, and cyclin D1 (Clone RBT14, Dako; 1:50) and p53 (Clone DO7, Santa Cruz; 1:200) were uniformly negative.

The patient was lost to follow-up and, therefore, subsequent staging procedures could not be performed. However, the initial clinical evaluation of a localized tumor in the nasal cavity as well as of the immunohistochemical expression profile of the neoplastic plasma cells are both consistent with a primary extramedullary plasmacytoma.

Various cytoarchitectural configurations of plasma cell neoplasms have already been described [2]. In the so-called 'nested' pattern, groups of plasma cells may be surrounded by thin fibrovascular septa mimicking a neuroendocrine tumor [2], whereas in the 'angiomatoid' pattern, areas composed of pseudovascular spaces - limited by neoplastic plasma cells - may give the impression of a vascular 
Fig. 1 Plasmacytoma with a follicle-like arrangement. a Irregular spaces limited by neoplastic mature plasma cells (inset, close up of the scalloped borders; HE); b the 'colloidlike' material is highlighted with the PAS method; c membranal CD138-positive immunostaining of the neoplastic cells
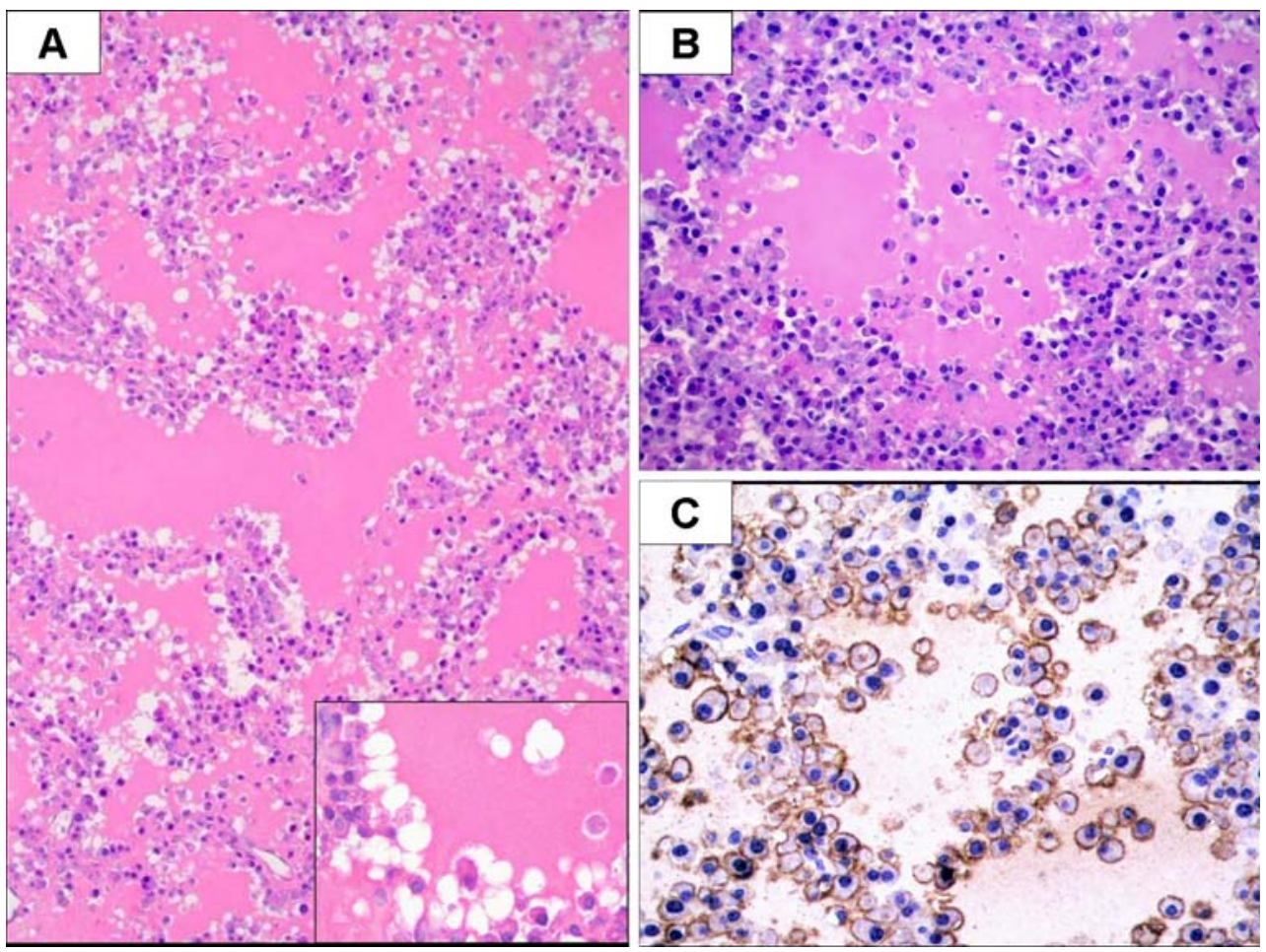

neoplasm. Presence of variable-sized spaces limited by neoplastic plasma cells was also observed in our case, thus resembling the 'angiomatoid' pattern. However, in the angiomatoid areas of plasma cell tumors, proliferation of numerous stromal blood vessels or pseudovascular spaces filled with erythrocytes are found [3]; both features were absent in our case. Moreover, it is important to consider the presence of homogeneous, proteinaceous eosinophilic material in the context of a plasmacytic proliferation, as it may correspond to light chain amyloid deposition [4]. Nonetheless, this was ruled out by the Congo red negative staining.

Interestingly, various malignant tumors arising in organs other than the thyroid may also exhibit a similar thyroid follicle-like pattern, such as juvenile granulosa cell tumor

Fig. 2 Immunoprofile of extramedullary plasmacytoma with follicle-like arrangement. The neoplastic cells and extracellular material are positive for kappa and negative for lambda light chains. Less than $2 \%$ of the neoplastic cells are positive for CD56, p21, and Ki-67; bcl-2 demonstrated a weak cytoplasmic staining in $15 \%$ of the tumor cells. Cyclin D1 and p53 are uniformly negative

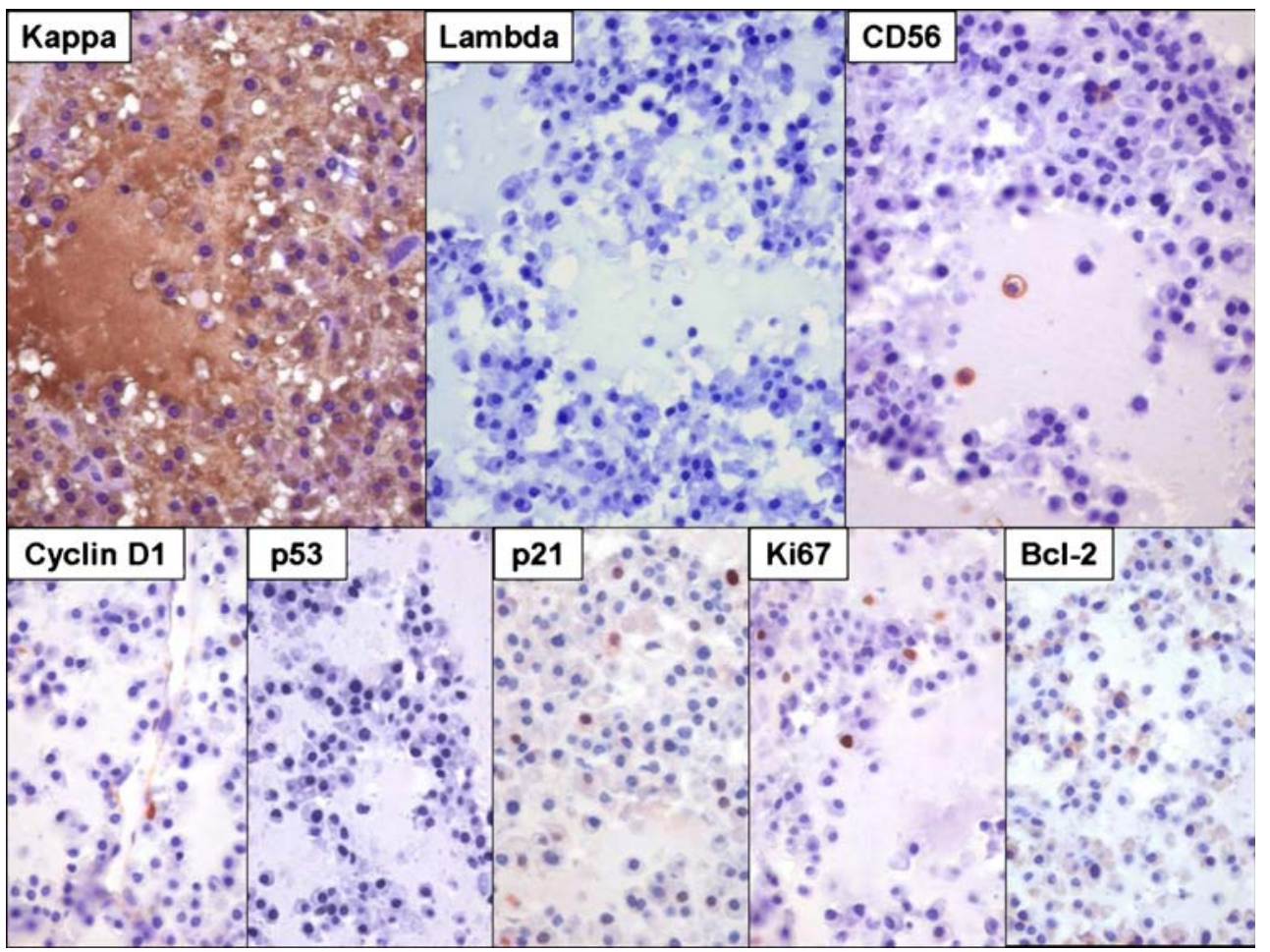


of the ovary [5], thyroid-like breast tumor [6], thyroid follicular carcinoma-like tumor of the kidney [7], acinic cell carcinoma with follicular pattern [8], and malignant melanoma [9]. To the best of our knowledge, this is the first report in the English literature of a plasma cell tumor displaying follicular and colloid-like structures, reminiscent of thyroid follicular histology.

Conflict of interest statement The authors declare that they have no conflict of interest.

\section{References}

1. Kremer M, Ott G, Nathrath M, Specht K, Stecker K, Alexiou C, Quintanilla-Martinez L, Fend F (2005) Primary extramedullary plasmacytoma and multiple myeloma: phenotypic differences revealed by immunohistochemical analysis. J Pathol 205:92-101
2. Banerjee SS, Verma S, Shanks JH (2004) Morphological variants of plasma cell tumours. Histopathology 44:2-8

3. Nandedkar MA, Abbondanzo SL, Miettinen M (2000) Extramedullary manifestation of multiple myeloma (systemic plasmacytoma) that simulates hemangioma. Arch Pathol Lab Med 124:628-631

4. Velez D, Hinojar-Gutierrez A, Nam-Cha S, Acevedo-Barbera A (2007) Laryngeal plasmacytoma presenting as amyloid tumour: a case report. Eur Arch Otorhinolaryngol 264:959-961

5. Young RH, Dickersin GR, Scully RE (1984) Juvenile granulosa cell tumor of the ovary. A clinicopathological analysis of 125 cases. Am J Surg Pathol 8:575-596

6. Eusebi V, Damiani S, Ellis IO, Azzopardi JG, Rosai J (2003) Breast tumor resembling the tall cell variant of papillary thyroid carcinoma: report of 5 cases. Am J Surg Pathol 27:1114-1118

7. Jung SJ, Chung JI, Park SH, Ayala AG, Ro JY (2006) Thyroid follicular carcinoma-like tumor of kidney: a case report with morphologic, immunohistochemical, and genetic analysis. Am J Surg Pathol 30:411-415

8. Bircan S, Kayaselcuk F, Yavuz H, Tuncer I (2004) Acinic cell carcinoma with follicular pattern of the soft palate. Pathol Res Pract 200:575-579

9. Gupta D, Deavers MT, Silva EG, Malpica A (2004) Malignant melanoma involving the ovary: a clinicopathologic and immunohistochemical study of 23 cases. Am J Surg Pathol 28:771-780 